\title{
Labor-input requirements for experimental production of drip irrigated vegetables'
}

\author{
Megh R. Goyal, Tillak Persaud and Luis E. Rivera ${ }^{2}$ \\ ABSTRACT
}

Weekly and operational labor input requirements were evaluated for experimental production of drip irrigated vegetables at the Fortuna Substation, Juana Díaz, Puerto Rico. The fotal man-hours per ha required in the plastic mulched plots were 1,964.1, 1,644.9, 1,412.7, 1,561, 1,247, 1,382 for peppers, cabbages, watermelons, cucumbers, snap beans (once-over harvest) and snap beans (multiple harvest), respectively. In the nonmulched plots, the man-hours were 1,899.8, 1,460.5, 1,119, 1,386, 1,247, and 1,387, respectively. Labor input for the tomato crop was 3,021.2, $1,891,2,2,591.1,1,467.1$ in the plastic-staked, non-plastic-staked, plasticnon-staked, non-plastic-non-staked plots, respectively. Pigeon peas (var. Koki) required 1,334.9 man-hours per ha; 2-B-Bushy variety required 1,368.9. Trickle irrigation installation and dismantling operations needed 4.1 to $16.1 \%$ of total labor input; plastic mulch management required 15.3 to $28.4 \%$. Weeding aperation amounted to 12.4 to $27.1 \%$ of total labor input compared with 28.4 to $62.6 \%$ for harvesting and post harvest operation. Use of plastic mulch reduced labor inputs for weeding operation to less than $4 \%$, depending upon crop type and season.

\section{INTRODUCTION}

Timeliness and intensity of field operations are the essential ingredients for a successful experiment. Shortages of manual labor at any time will cause tardy or inadequate performance of activities. There are two cropping seasons in Puerton Rico-summer (April to September) and winter (October to March). ${ }^{3}$ The authors found that the energy needs were maximum for harvesting and post harvest operations during the production of peppers (var. Cubanelle). ${ }^{3}$

This study estimated operational labor input requirements for an experimental production of drip irrigated peppers, cabbages, tomatoes, and

'Manuscript submitted to Editorial Board 23 January 1987.

This study was conducted under H-326 (S-143), Southern Regional Research Project"Trickle Irrigation in Humid Regions" and CBAG-PR-23-"Irrigation Estimations in Puerto Rico."

${ }^{3}$ Associate Agricultural Engineer, Associate Economist, and Research Assistant, Agricultural Experiment Station, University of Puerto Rico, Mayagüez Campus, Río Piedras, Puerto Rico.

${ }^{3}$ Goyal, M. R., 1988. Labor-input requirements for experimental production of summer peppers under drip irrigation. J. Agric. Unin. P. R. 67 (1): 22-7. 
pigeon peas during the winter, and watermelons, cucumbers and snap beans during the summer at Fortuna Substation, Juana Díaz, Puerto Rico.

\section{MATERIALS AND METHODS}

The field experiment $t^{4}$ on varying water application rates on peppers, cabbage, tomato, pigeon peas, cucumber, snap beans and watermelon was used to estimate the operational labor requirements for the experimental production of these vegetables. The whole field was considered as a single unit for the purpose of this study. Field operations were identified as land preparation, drip irrigation installation, plastic mulch installation, planting, soil treatment, fertilization, spraying, weeding, harvesting, post harvest operations, removal of drip irrigation system, removal of plastic mulch, tensiometer use, staking and tying, removal of stakes, and miscellaneous.

Beds were shaped with a bed shaper for $1.8 \mathrm{~m}$ spacing in all crops except for $0.9 \mathrm{~m}$ spacing in pigeon peas. Silver-coated black plastic mulch (0.0015 gauge) was manually placed over the desired beds. A 5-cm diameter galvanized pipe was used to punch the hole in the plastic at the desired positions. Plot size was $10.8 \times 162 \mathrm{~m}$ (90 beds, each $10.8 \mathrm{~m}$ long) for all crops except pigeon peas [10.8 $\times 81 \mathrm{~m}$ (90 beds, each $10.8 \mathrm{~m}$ long) $]$. Treatments wore plastic mulching and non-mulching for peppers and cabbage during the winter, and watermelons, cucumbers and snap beans during the summer; Kaki and 2-B-Bushy pigeon peas during the winter and plastic mulching-staking (PS), plastic mulching-non-staking (PNS), non-mulching-staking (NPS), non-mulching-non-staking (NPNS) for tomato during the winter. Fertilizer, fungicides and insecticides were applied as needed according to recommendations of the Agricultural Experiment Station, University of Puerto Rico. ${ }^{5}$

Table 1 indicates agronomical practices for these crops. The daily labor requirement to complete each operation was recorded; these data were used to calculate labor input requirement (man-hours/ha and percent distribution) as shown in tables 2 and 3.

\section{RESULTS AND DISCUSSION}

Table 2 presents operational labor-input requirements for experimental production of selected vegetables. Table 3 shows percentile distribution of labor requirements for various operations during the crop season. A tractor was used for land preparation and spray applications. All other operations were completed manually.

'Trickle Irrigation in Humid Regions-Puerto Rico. Annual Report No. 1/Puerto Rico/ Hatch 326 (S-143)/1979-80 and No. 2/Puerto Rico/Hateh 326 (S-143)/1980-81, Agricultural Experiment Station, Río Piedras, P. R.

"Conjunto Tecnológico Para La Producción de Hortalizas, 1979. Publ. 102, Esta. Exp. Agric. Univ. P. R. 
TABLE 1.-Agronomical practices in dirip imigated vegetables at Fortuna Substation

\begin{tabular}{|c|c|c|c|c|c|c|c|c|c|c|}
\hline \multirow{2}{*}{ Crop } & \multirow{2}{*}{ Variety } & \multirow{2}{*}{ Treatment } & \multirow{2}{*}{$\begin{array}{l}\text { Bed } \\
\text { spacing }\end{array}$} & \multirow{2}{*}{$\begin{array}{l}\text { Drip } \\
\text { type }\end{array}$} & \multirow{2}{*}{ Date } & \multirow{2}{*}{$\begin{array}{c}\text { Spacing } \\
\text { within } \\
\text { the row }\end{array}$} & \multirow{2}{*}{$\begin{array}{l}\text { Plants } \\
\text { per ha }\end{array}$} & \multirow{2}{*}{$\begin{array}{l}\text { Distance } \\
\text { away from } \\
\text { drip line }\end{array}$} & \multicolumn{2}{|c|}{$\begin{array}{l}\text { Planting pattern } \\
\text { down the drip line }\end{array}$} \\
\hline & & & & & & & & & One side & Both sides \\
\hline $\begin{array}{l}\text { Peppers } \\
\text { (winter) }\end{array}$ & Cubanelle & $\begin{array}{c}\mathrm{P} \\
\mathrm{NP}\end{array}$ & $\begin{array}{l}\mathrm{cm} \\
180 \\
180\end{array}$ & Bi wall & $\begin{array}{l}11-18-80 \\
11-18-80\end{array}$ & $\begin{array}{l}\mathrm{cm} \\
30 \\
30\end{array}$ & $\begin{array}{l}37,037 \\
37,037\end{array}$ & $\begin{array}{r}c m \\
15 \\
15\end{array}$ & - & $\begin{array}{l}\text { yes } \\
\text { yes }\end{array}$ \\
\hline $\begin{array}{l}\text { Peppers } \\
\text { (summer) }\end{array}$ & Cubanelle & $\stackrel{\mathrm{P}}{\mathrm{NP}}$ & $\begin{array}{l}180 \\
180\end{array}$ & " & $\begin{array}{l}11-18-80 \\
11-18-80\end{array}$ & $\begin{array}{l}30 \\
30\end{array}$ & $\begin{array}{l}37,037 \\
37,037\end{array}$ & $\begin{array}{l}15 \\
15\end{array}$ & - & $\begin{array}{l}\text { yes } \\
\text { yes }\end{array}$ \\
\hline Cabbage & $\begin{array}{l}\text { Market } \\
\text { Prize }\end{array}$ & $\begin{array}{c}\mathrm{P} \\
\mathrm{NP}\end{array}$ & $\begin{array}{l}180 \\
180\end{array}$ & $"$ & $\begin{array}{l}11-25-80 \\
11-25-80\end{array}$ & $\begin{array}{l}30 \\
30\end{array}$ & $\begin{array}{l}37,037 \\
37,037\end{array}$ & $\begin{array}{l}15 \\
15\end{array}$ & - & $\begin{array}{l}\text { yes } \\
\text { yes }\end{array}$ \\
\hline Tomatoes & Walter & $\begin{array}{c}\text { PS } \\
\text { NPS } \\
\text { PNS } \\
\text { NPNS }\end{array}$ & $\begin{array}{l}180 \\
180 \\
180 \\
180\end{array}$ & " & $\begin{array}{l}11-13-80 \\
11-13-80 \\
11-13-80 \\
11-13-80\end{array}$ & $\begin{array}{l}30 \\
38 \\
30 \\
30\end{array}$ & $\begin{array}{l}18,518 \\
18,518 \\
18,518 \\
18,518\end{array}$ & $\begin{array}{l}15 \\
15 \\
15 \\
15\end{array}$ & $\begin{array}{l}\text { yes } \\
\text { yes } \\
\text { yes } \\
\text { yes }\end{array}$ & $\begin{array}{l}- \\
-\end{array}$ \\
\hline Pigeon peas & $\begin{array}{l}\text { Kaki; } \\
\text { 2-B, Bushy }\end{array}$ & - & $\begin{array}{l}90 \\
90\end{array}$ & $"$ & $\begin{array}{l}8-10-80 \\
8-10-80\end{array}$ & $\begin{array}{l}15 \\
15\end{array}$ & $\begin{array}{l}148,148 \\
148,148\end{array}$ & $\begin{array}{l}7.5 \\
7.5\end{array}$ & - & $\begin{array}{l}\text { yes } \\
\text { yes }\end{array}$ \\
\hline Watermelons & $\begin{array}{l}\text { Charleston } \\
\text { Gray }\end{array}$ & $\begin{array}{l}\mathrm{P} \\
\mathrm{NP}\end{array}$ & $\begin{array}{l}180 \\
180\end{array}$ & $"$ & $\begin{array}{l}3-18-81 \\
3-18-81\end{array}$ & $\begin{array}{l}30 \\
30\end{array}$ & $\begin{array}{l}9,259 \\
9,259\end{array}$ & $\begin{array}{l}15 \\
15\end{array}$ & $\begin{array}{l}\text { yes } \\
\text { yes }\end{array}$ & - \\
\hline Cucumbers & $\begin{array}{l}\text { Poinsett } \\
76\end{array}$ & $\begin{array}{c}\mathrm{P} \\
\mathrm{NP}\end{array}$ & $\begin{array}{l}180 \\
180\end{array}$ & " & $\begin{array}{l}3-31-80 \\
3-31-80\end{array}$ & $\begin{array}{l}60 \\
60\end{array}$ & $\begin{array}{l}148,148 \\
148,148\end{array}$ & $\begin{array}{l}15 \\
15\end{array}$ & - & $\begin{array}{l}\text { yes } \\
\text { yes }\end{array}$ \\
\hline Snap beans & $\begin{array}{l}\text { Bush Blue } \\
\text { Lake } 47\end{array}$ & $\underset{\mathrm{NP}}{\mathrm{P}}$ & $\begin{array}{l}180 \\
180\end{array}$ & $"$ & $\begin{array}{l}6-17-80 \\
6-17-80\end{array}$ & $\begin{array}{l}15 \\
15\end{array}$ & $\begin{array}{l}148,148 \\
148,148\end{array}$ & $\begin{array}{l}7.5 \\
7.5\end{array}$ & - & $\begin{array}{l}\text { yes } \\
\text { yes }\end{array}$ \\
\hline
\end{tabular}

D

'P = plastic; PNS = plastic-no stakes; NPNS = no plastic-no stakes; NP = no plastic; PS = plastic-stakes; NPS = no plastic-stakes. 
TABLE 2.-Operational labor input requirements for experimental production of summer and uinter vegetable crops under drip irrigation during 1980-81

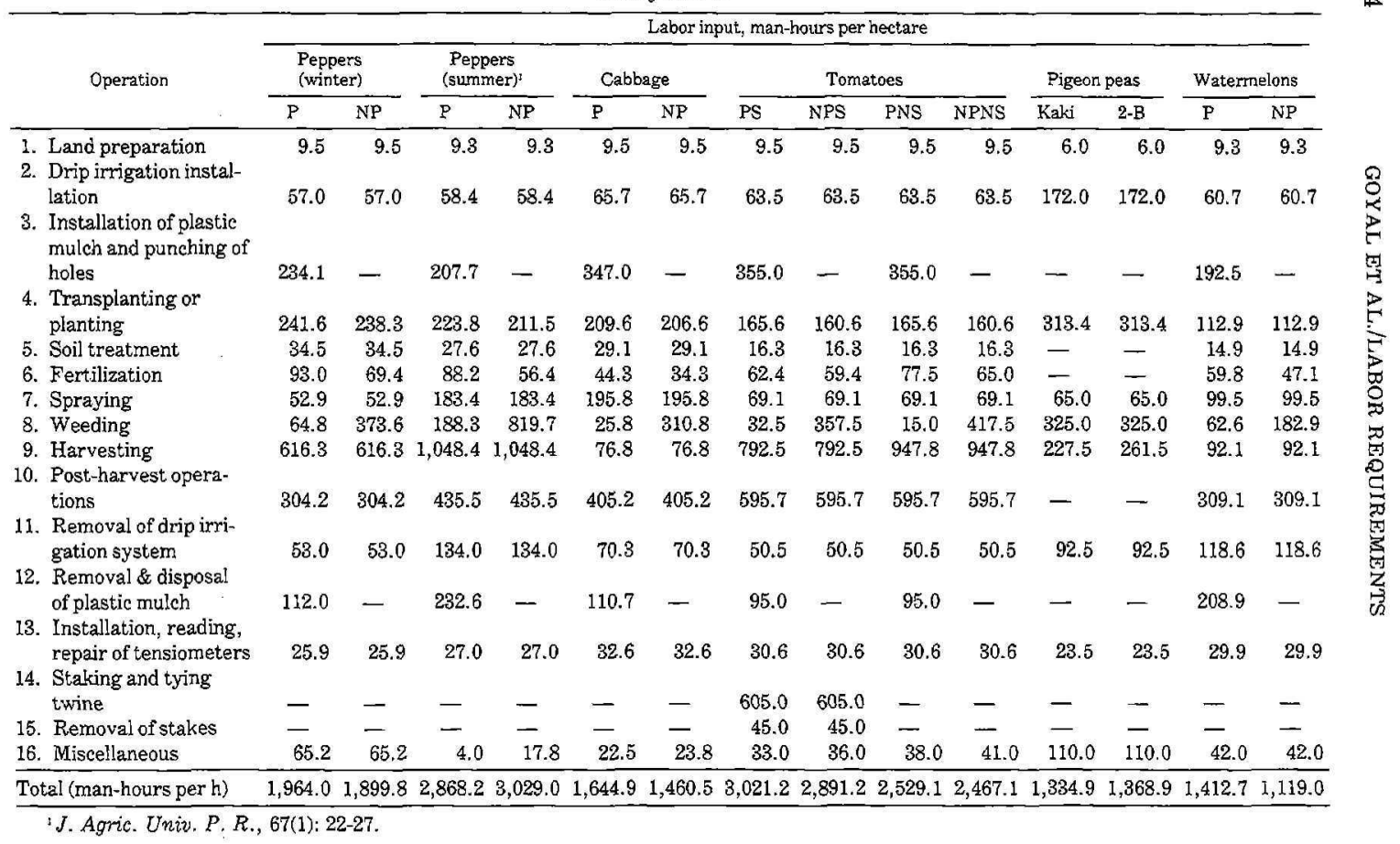


Peppers-Tables 2 and 3 present the analyzed data. Total labor input during the crop season 1,964 and 1,899.8 man-hours per ha in mulched and non-mulched plots, respectively. Tensiometer installation, repair, reading, servicing operations required 21.3 man-hours per ha. Disposal of plastic mulch required 112 man-hours per ha; dismantling of the drip irrigation system, 53.

In plastic-mulched plots, the highest percentage of labor input was $22.7 \%$, during the 17th week for the 5th picking/dismantling of the drip irrigation system/disposal of plastic mulch. Plastic mulch layout required $11.9 \%$ of the total labor input. Transplanting, soil treatment, drip irrigation installation, land preparation, and plastic mulch layout operations required $27.9 \%$ of the labor input during the first week. In the nonmulched plots, these operations required $16.5 \%$ of the labor input during the first week. The highest percentage of labor input was $17.6 \%$ the $17 \mathrm{th}$ week. Harvesting, grading, handling, and weighing constituted $46.9 \%$ and $48.4 \%$ of labor input in mulched and non-mulched plots, respectively. Transplanting required $12.3 \%$ of labor input in mulched plots; $12.5 \%$ in non-mulched plots. Weeding operation accounted for $19.7 \%$ of labor in non-mulched plots, $3.3 \%$ in mulched plots. Plastic mulch management used a labor input of $17.5 \%$. Man-hours per ha requirements were 9.5 for land preparation; 57 for drip irrigation installation; 34.5 for soil treatment; 52.9 for spraying; 920.5 for harvesting/handling/weighing; 53 for dismantling of drip system; 25.9 for installation/reading/repair/servicing of tensiometers; and 65.2 for miscellaneous purposes in the mulched and non-mulched plots. Plastic mulch management required 346.1 man-hours per ha. Transplanting, fertilization, weeding operations required 241.6, 93 , and 64.8 man-hours per ha, respectively, in the mulched plots; 238.3 , 69.4 and 373.6 man-hours per ha in the non-mulched plots, respectively. Weeding required $27 \%$ of labor input in the summer ${ }^{3}$ and $19.7 \%$ in the winter in the non-mulched plots.

Cabbage-Tables 2 and 3 present the analyzed data. Total labor input during the crop season was $1,644.9$ and 1,460.5 man-hours per ha in plastic-mulched and non-mulched plots, respectively. Tensiometer repair, reading and servicing operations consumed 32.6 man-hours per ha. Labor input requirements were highest on the 65th day. Installation of plastic mulch consumed 347.7 man-hours per ha. In the mulched plots, highest percentage of labor input was $21.2 \%$ for plastic mulch layout during the first week. Land preparation, drip irrigation installation, plastic mulch installation, transplanting, and soil treatment operations used $39.3 \%$ of labor input during the first week. In non-mulched plots, these operations consumed $20.6 \%$ of the labor input during the first week. Highest percentage of labor input was $18.9 \%$ during the tenth week and for first picking. Transplanting required $14.1 \%$ of the labor input in non- 
TABLE 3.-Percentile distribution of operational labor input requirements for experimental production of summer and winter vegetable crops under drip irrigation durring 1980-81

\begin{tabular}{|c|c|c|c|c|c|c|c|c|c|c|c|c|c|c|}
\hline \multirow{3}{*}{ Operation' } & \multicolumn{14}{|c|}{ Labor input, percent of total } \\
\hline & \multicolumn{2}{|c|}{$\begin{array}{l}\text { Peppers } \\
\text { (winter) }\end{array}$} & \multicolumn{2}{|c|}{$\begin{array}{c}\text { Peppers } \\
\text { (summer)' }\end{array}$} & \multicolumn{2}{|c|}{ Cabbage } & \multicolumn{4}{|c|}{ Tomatoes } & \multicolumn{2}{|c|}{ Pigeon peas } & \multicolumn{2}{|c|}{ Watermelons } \\
\hline & $P$ & NP & $\mathrm{P}$ & NP & $\mathbf{P}$ & NP & PS & NPS & PNS & NPNS & Kaki & $2-B$ & $\mathrm{P}$ & NP \\
\hline $\begin{array}{l}\text { 1. Land preparation } \\
\text { 2. Drip irrigation instal- }\end{array}$ & 0.5 & 0.5 & 0.3 & 0.3 & 0.6 & 0.7 & 0.3 & 0.3 & 0.4 & 0.4 & 0.4 & 0.4 & 0.7 & 0.8 \\
\hline $\begin{array}{l}\text { lation } \\
\text { 3. Layout of plastic } \\
\text { mulch and punching }\end{array}$ & 2.9 & 3.0 & 2.0 & 1.9 & 4.0 & 4.5 & 2.1 & 2.2 & 2.5 & 2.6 & 12.9 & 12.6 & 4.3 & 5.4 \\
\hline $\begin{array}{l}\text { of holes } \\
\text { 4. Transplanting or }\end{array}$ & 11.9 & 一 & 7.2 & - & 21.0 & - & 11.8 & - & 14.0 & - & - & - & 13.6 & 一 \\
\hline planting & 12.3 & 12.5 & 7.8 & 7.0 & 12.7 & 14.1 & 5.5 & 5.6 & 6.5 & 6.5 & 23.5 & 22.9 & 8.0 & 10.1 \\
\hline 5. Soil treatment & 1.8 & 1.8 & 1.0 & 0.9 & 1.8 & 2.0 & 0.5 & 0.6 & 0.6 & 0.7 & - & - & 1.1 & 1.3 \\
\hline 6. Fertilization & 4.7 & 3.7 & 3.1 & 1.9 & 2.7 & 2.3 & 2.1 & 2.1 & 3.1 & 2.6 & - & - & 4.2 & 4.2 \\
\hline 7. Spraying & 2.7 & 2.8 & 6.4 & 6.1 & 11.9 & 13.4 & 2.3 & 2.4 & 2.7 & 2.8 & 4.9 & 4.7 & 7.0 & 8.9 \\
\hline 8. Weeding & 3.3 & 19.7 & 6.6 & 27.1 & 1.6 & 21.3 & 1.1 & 12.4 & 0.6 & 16.9 & 24.3 & 23.7 & 4.4 & 16.3 \\
\hline 9. Harvesting & 31.4 & 32.4 & 36.6 & 34.5 & 4.7 & 5.3 & 26.2 & 27.3 & 37.5 & 38.5 & 17.0 & 19.2 & 4.4 & 8.2 \\
\hline 10. Post-harvest opera- & & & & & & & & & & & & & & \\
\hline $\begin{array}{l}\text { tions } \\
\text { 11. Dismantling drip irri- }\end{array}$ & 15.5 & 16.0 & 15.2 & 14.4 & 24.6 & 27.8 & 19.7 & 20.6 & 23.6 & 24.1 & 一 & - & 21.9 & 27.6 \\
\hline $\begin{array}{l}\text { 12. Removal \& disposal } \\
\text { Rem system }\end{array}$ & 2.7 & 2.8 & 4.7 & 4.4 & 4.3 & 4.8 & 1.7 & 1.7 & 2.0 & 2.0 & 6.9 & 6.8 & 8.4 & 10.6 \\
\hline of plastic mulch & 5.7 & - & 8.1 & - & 6.7 & 一 & 3.1 & - & 3.8 & - & - & - & 14.8 & - \\
\hline $\begin{array}{l}\text { 13. Installation, reading, } \\
\text { repair of tensiometers }\end{array}$ & 1.3 & 1.4 & 0.9 & 0.9 & 2.0 & 2.2 & 1.0 & 1.1 & 1.2 & 1.2 & 1.8 & 1.7 & 2.1 & 2.8 \\
\hline $\begin{array}{l}\text { 14. Staking and tying } \\
\text { twine }\end{array}$ & - & - & - & - & - & - & 20.0 & 20.9 & - & - & - & - & - & - \\
\hline 15. Removal of stakes & - & - & - & - & - & - & 1.5 & 1.6 & - & - & - & - & - & - \\
\hline 16. Miscellaneous & 3.3 & 3.4 & 0.1 & 0.6 & 1.4 & 1.6 & 1.1 & 1.2 & 1.5 & 1.7 & 8.3 & 8.0 & 3.0 & 3.8 \\
\hline Total (man-hours per ha) & $1,964.0$ & $1,899.8$ & $2,868.2$ & $3,029.0$ & $1,644.9$ & $1,460.5$ & $3,021.2$ & $2,891.2$ & $2,529.1$ & $2,467.1$ & $1,334.9$ & $1,368.9$ & $1,412.7$ & $1,119.0$ \\
\hline Total (percent) & 100.0 & \pm 00.0 & 100.0 & 100.0 & 100.0 & 100.0 & 100.0 & 100.0 & 100.0 & 100.0 & 100.0 & 100.0 & 100.0 & 100.0 \\
\hline
\end{tabular}

'Note: To calculate man-hrs/ha for each operation, multiply total man-hrs/ha by percent of total. Conversion may not be exact due to rounding. JJ. Agric. Univ. P. R., 67(1): 22-27. 
mulched plots; $12.7 \%$ in mulched plots. The use of plastic mulch required a labor input of $27.7 \%$. Weeding required $1.6 \%$ of the labor input in the mulched plots; $21.3 \%$ in the non-mulched plots. Spraying accounted for $11.9 \%$ of the labor input in mulched plots; $13.4 \%$ in non-mulched plots. Harvesting, grading, handling, and weighing needed $29.3 \%$ and $33.1 \%$ of the labor input in mulched and non-mulched plots, respectively. Installation and removal of the drip irrigation system required $8.3 \%$ of total labor input in mulched plots. Man-hours per ha requirements were 9.5 for land preparation; 65.7 for drip irrigation installation; 29.1 for soil treatment; 195.8 for spraying; 482 for harvesting/post harvest operations; 70.3 for removal of drip system; and 32.6 for installation/repair/reading/ servicing of tensiometers in the mulched and non-mulched plots. Plastic mulch management required 457 man-hours per ha. Transplanting, weeding, fertilizing required $209.6,25.8$, and 44.3 man-hours per ha, respectively in mulched plots; 206.6, 310.8 and 34.3 man-hours per ha in nonmulched plots.

Tomato-Tables 2 and 3 present the analyzed data. Total labor requirements during the crop season were 3,021.2 man-hours per ha for plastic-mulehed-staked (PS), 2,891.2 for non-mulched-staked (NPS), 2,529.1 for plastic mulched-non-staked (PNS), and 2,467.1 for nonmulched-non-staked (NPNS) tomatoes, respectively. During the first week, land preparation, drip irrigation installation, plastic mulch layout, transplanting, and soil treatment needed $20.3,24.3,8.8$ and $10.4 \%$ of total input in the PS, PNS, NPS, and NPNS, respectively. Man-hour per ha requirements in all plots (PS, NPS, PNS, NPNS) were 9.5 for land preparation, 63.5 for irrigation installation, 16.3 for soil treatment, 69.1 for plant protection, 595.7 for grading, handling, and weighing, 50.5 for the removal of the drip system, and 30.6 for installation, reading, and servicing of tensiometers.

Plastic mulched and staked tomatoes (PS) - The highest percentage of labor input was $16.1 \%$ during the 12 th week when the second picking, fertilization, and the seventh spraying were required. Transplanting required only $5.5 \%$ of the labor input. The use of plastic mulch required $14.9 \%$, whereas staking and tying required $25.1 \%$ of the labor input. Harvesting, grading, handling, and weighing required $45.9 \%$ of the total labor input. Drip irrigation installation and removal required only $3.8 \%$ of the labor input, whereas weeding and spraying accounted for 1.1 and $2.3 \%$, respectively. Man-hours per ha requirements were 355 for installing plastic mulch, 165.6 for transplanting, 62.4 for fertilizing, 32.5 for weed control, 650 for installing and removing of stakes, 792.5 for harvesting, 95 for disposal of plastic mulch, and 33 for miscellaneous purposes. 
Plastic mulched and non-staked tomatoes (PNS) - - The highest percentage of labor input was $21.6 \%$ during the 12 th week for the second picking, fertilization, and the seventh spraying. Transplanting required $6.5 \%$ of the labor input. The use of plastic mulch required a labor input of $18 \% ; 4.4 \%$ for installation and removal of the drip system; $0.6 \%$ for weed control, $2.7 \%$ for spraying; and $61.1 \%$ for harvesting, grading, weighing, and handling. Man-hours per ha requirements were 355 for installing the plastic mulch; $165.6 \%$ for transporting; 77.5 for fertilizing; 15 for weed control; 947.8 for harvesting; 95 for disposal of plastic mulch; and 38.8 for miscellaneous purposes.

Non-mulched and staked tomatoes (NPS) - The highest percentage of labor input was $16.9 \%$ during the 12th week: the second picking, fertilization, and the seventh spraying. Transplanting, drip irrigation installation and removal, weed control, spraying, harvesting, and post harvest operations, and installing and removal of stakes consumed $5,6,3,9,12.4$, $2.4,47.8$, and $22.4 \%$ of the total labor input, respectively. Man-hours per ha requirements were 160.6 for transplanting; 59.4 for fertilizing; 357.5 for weeding; 650 for staking and removal of stakes; 792.5 for harvesting; and 36 for miscellaneous purposes.

Non-mulched and non-staked tomatoes (NPNS) - The highest percentage of labor input was $21.6 \%$, also during the 12 th week. Transplanting, drip irrigation installation and removal, weed control, spraying, and harvest and post harvest operations required 6.5, 4.6, 16.9, 2.8, and $62.6 \%$ of the total labor input, respectively. Man-hour per ha requirements were 160.6 for transplanting; 65 for fertilizing; 417.5 for weed control; 947.8 for harvesting; and 41 for miscellaneous purposes.

Pigeon peas-Tables 2 and 3 present the analyzed data. Total labor input during the crop season was $1,334.9$ and 1,368 man-hours per ha for Kaki and 2-B-Bushy, respectively. Installation, reading and servieing of moisture cells required 23.5 man-hours in both varieties. Labor input was highest on the 19th day. The highest percentage of labor input was $25.5 \%$ for Kaki and $24.8 \%$ for 2-B-Bushy during the third week, for the first weeding and spraying. Land preparation, drip irrigation installation, planting operations used $30.1 \%$ of the labor input during the first week for Kaki; $29.3 \%$ of labor input in case of 2-B-Bushy. Planting required 23.5 and $22.9 \%$ of labor input to Kaki and 2-B-Bushy. Harvesting and post harvest operations required 17 and $19.2 \%$ of the labor input in Kaki and 2-B-Bushy. Man-hours per ha requirements were 6 for land preparation, 172 for drip irrigation installation, 313.4 for planting, 405 for weeding and thinning, 65 for spraying, 23.5 for installation/servicing/ reading of moisture cells, and 30 for miscellaneous purposes in both varieties. Harvesting and post harvest operations required 227.5 and 261.5 man-hours per ha in Kaki and 2-B-Bushy varieties, respectively. 
Watermelon-Tables 2 and 3 present the analyzed data. Total labor input during the crop season was 1,412.7 and 1,119 man-hours per ha in the $\mathrm{P}$ and NP plots, respectively. Tensiometer installation, reading, and servicing required 29.9 man-hours per ha in both $\mathrm{P}$ and NP plots. Disposal of plastic mulch required 208.9 man-hours per ha; 118.6 for removal of the irrigation system. Nursery operations needed 37 man-hours per ha. In the P plots, the highest labor input was $23.2 \%$. During the 17th week the drip system and plastic mulch were removed. During the first week $30.6 \%$ of total labor was required, $17 \%$ of which was used for land preparation, soil treatment, installation of drip system, and transplanting, whereas $13.6 \%$ was required to install the plastic mulch. In NP plots, only $21.5 \%$ of the labor input was used during the first week, whereas the highest weekly labor input of $21.7 \%$ occurred during the 12 th week. Transplanting required $8 \%$ of total labor in $\mathrm{P}$ plots, $10.1 \%$ in NP plots. Weeding required $4.4 \%$ of the labor input in P plots, $6.3 \%$ in NP plots. Spraying required $7 \%$ and $8.9 \%$ of total labor in P and NP plots, respectively. Harvesting and post harvest operations required 28.4 and $35.8 \%$ of labor input in the P and NP plots, respectively. Plastic mulch management required a labor input of $28.4 \%$. Man-hours per ha were 9.5 for land preparation, 37 for nursery operations, 60.7 for installation of drip system, 112.9 for transplanting, 99.5 for plant protection, 401.2 for harvesting and post harvest operations, 118.6 for removal of drip system, 29.9 for installation, reading, and servicing of tensiometers, and 5 for incidental operations in the P and NP plots. Plastic mulch management required 401.4 man-hours per ha, 208.9 of which were required for removal of plastic mulch. Fertilization and weeding operations required 59.8 and 62.5 man-hours per ha in the P plots; 47.1 and 182.9 in the NP plots, respectively.

Cucumbers-Total labor requirements were 1,561 man-hours per hectare for the crop season. Highest percentage of labor-input was $22.3 \%$ during the seventh week and for the first, second, and third pickings. The last two pickings required a labor input of $20.3 \%$ during the 9th week. Harvesting, grading, and weighing operations constituted $51.5 \%$ of total labor input. Man-hours per hectare requirements were 804 for harvesting and post harvest operations, 231 for weeding, 175 for plastic mulch management, and 129 for trickle irrigation installation.

Snap beans-There were no labor requirements for land preparation, trickle irrigation and plastic mulch layout because the old cucumber field was used for this experiment. The total seasonal labor input for once-over harvest system was 1,247 man-hours per hectare and 1,382 man-hours per hectare for multiple-harvest system. The dismantling of the trickle system required 51 man-hours per hectare. The highest percentage of labor input was during the first week for planting and soil sterilization. 
Harvesting, grading, and weighing constituted $26 \%$ of the total labor input; weeding required $16.8 \%$.

\section{RESUMEN}

Mano de obra necesaria para producir hortalizas experimentalmente regadas por goteo

Aspectos de la producción experimental de hortalizas regadas por gofeo en terreno con cubiertas plásticas y se examinaron en la Subestación de Fortuna en Juana Díaz, Puerto Rico. El trabajo total en horas-hombre fue $1,964,1,644.9,1,412.7,1,561,1,247$ y 1,382 en pimiento, repollo, sandía, pepinillo, habichuela tierna (una sola consecha) y habichuela tierna (varias cosechas) en contraste con $1,899.8,1,460.5,1,119,1,386,1,247$ y 1,387 en las parcelas sin cubierta, respectivamente. La mano de obra necesaria en tomates fue $3,021.2,1,891.1,2,591$.1, 1,467.1 en las parcelas con plástico y estacas, sin plástico con estacas, plástico sin estacas y sin plástico y sin estacas, respectivamente. Se requirieron 1,334.9 horas-hombre por hectárea en gandul (var. Kaki) y 1,368,9 para la variedad 2-B-Bushy. La instalación $y$ desmantelamiento del sistema de riego por goteo requirió entre 4.1 a $16.1 \%$ de la mano de obra total, y de 15.3 a $28.4 \%$ para colocar $y$ levantar las cubiertas plásticas. El desyerbo requiríb entre 12.4 a $27.1 \%$ de la labor tofal; y cosechar otras labores posteriores requirieron de 28.4 a 62.6\%. El uso de la cubierta plástica redujo la mano de obra del desyerbo a menos de $\mathbf{4 \%}$ dependiendo de la hortaliza y la estación del año. 